\title{
Archaeological Testing of Site 41BX1199, Government Canyon State Natural Area, Bexar County, Texas
}

Jason D. Weston

Follow this and additional works at: https://scholarworks.sfasu.edu/ita

Part of the American Material Culture Commons, Archaeological Anthropology Commons, Environmental Studies Commons, Other American Studies Commons, Other Arts and Humanities Commons, Other History of Art, Architecture, and Archaeology Commons, and the United States History Commons

Tell us how this article helped you.

This Article is brought to you for free and open access by the Center for Regional Heritage Research at SFA ScholarWorks. It has been accepted for inclusion in Index of Texas Archaeology: Open Access Gray Literature from the Lone Star State by an authorized editor of SFA ScholarWorks. For more information, please contact cdsscholarworks@sfasu.edu. 


\section{Archaeological Testing of Site 41BX1199, Government Canyon State Natural}

Area, Bexar County, Texas

\section{Creative Commons License}

\section{(c) (1) \&}

This work is licensed under a Creative Commons Attribution-NonCommercial 4.0 International License 


\title{
Archaeological Testing of Site 41BX1199, Government Canyon State Natural Area, Bexar County, Texas
}

\author{
Jason D. Weston
}

Center for Archaeological Research

The University of Texas at San Antonio Archaeological Survey Report, No. 323

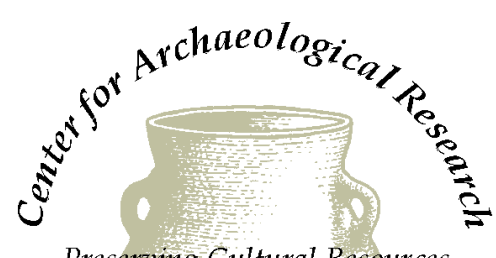

Preserving Cultural Resources

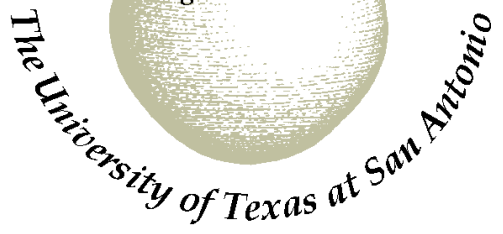




\title{
Archaeological Testing of Site 41BX1199, Government Canyon State Natural Area, Bexar County, Texas
}

\author{
Jason D. Weston
}

Russell D. Greaves and Steve A. Tomka Principal Investigators

Texas Antiquities Permit No. 2582

Ccopyright 2001

Center for Archaeological Research

The University of Texas at San Antonio

Archaeological Survey Report, No. 323 
The following information is provided in accordance with the General Rules of Practice and Procedure, Chapter 41.11 (Investigative Reports), Texas Antiquities Committee:

1. Type of investigation: Testing

2. Project name: Government Canyon State Natural Area (41BX1199)

3. County: Bexar

4. Principal investigator(s): Russell D. Greaves and Steve A. Tomka

5. Name and location of sponsoring agency: Texas Parks and Wildlife Department, 4200 Smith School Road, Austin, TX 78744-3292

6. Texas Antiquities Permit No.: 2582

7. Published by the Center for Archaeological Research, The University of Texas at San Antonio, 6900 N. Loop 1604 W., San Antonio, Texas 78249-0658, 2001

A list of publications offered by the Center for Archaeological Research is available. Call (210) 458-4378; write to the Center for Archaeological Research, The University of Texas at San Antonio, 6900 N. Loop 1604 W., San Antonio, Texas 78249-0658; e-mail to car@lonestar.utsa.edu; or visit CAR’s web site at http:/car.utsa.edu. 


\begin{abstract}
In May 2001, the Center for Archaeological Research (CAR), The University of Texas at San Antonio, tested two areas of site 41BX1199 in the Government Canyon State Natural Area. The Natural Area is located in northwest Bexar County and is under the ownership and management of the Texas Parks and Wildlife Department (TPWD). In advance of opening the Natural Area for public use, TPWD contracted with the CAR to conduct a 100 percent pedestrian survey of proposed trail systems within the property and to carry out National Register eligibility testing of site 41BX1199. CAR personnel conducted the testing of 41BX1199 under Texas Antiquities Permit 2582. This report discusses only the results of the test excavations performed at 41BX1199.

Two spatially isolated portions of site 41BX1199 were to be impacted by the construction of picnic locations and camping facilities. The two areas covered 7 acres ( 2.8 hectares) and 11.6 acres ( 4.7 hectares), respectively. The CAR testing efforts focused on these areas. Thirty-five shovel tests and one 1-x-1- meter test unit were excavated in the larger area, while 14 shovel tests were dug in the smaller area.

Testing efforts identified a low-density, disturbed surface scatter of artifacts and a modern hearth feature. No temporal diagnostic artifacts were recovered. The sparse collection of lithic artifacts, the lack of temporal diagnostics, the deflated character of some of the deposits, and the modern hearth feature suggested that the examined portions of 41BX1199 have low research potential and are not eligible for listing on the National Register of Historic Places or designation as a State Archeological Landmark. It is recommended that the area connecting the two impact zones be periodically examined for exposed artifacts that may come to light as a result of pedestrian and equestrian traffic. It is further recommended that an archaeologist monitor the work to be carried out in the impact zones and document any intact cultural materials encountered during construction.
\end{abstract}




\section{Contents}

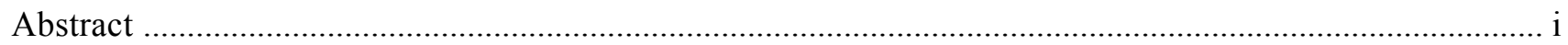

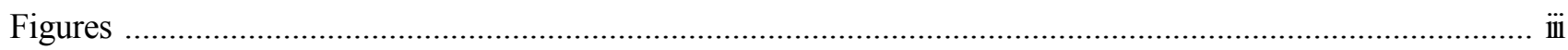

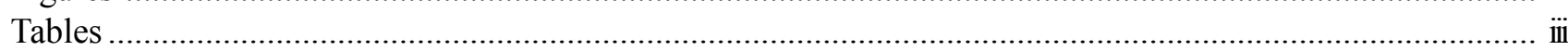

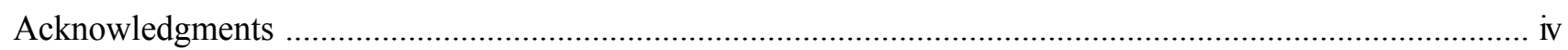

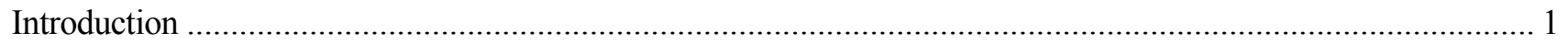

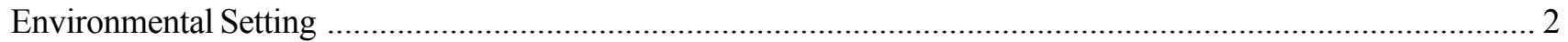

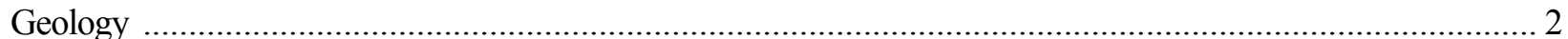

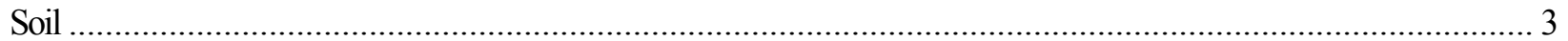

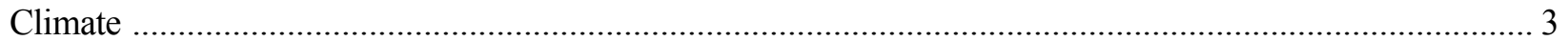

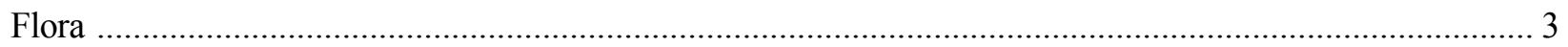

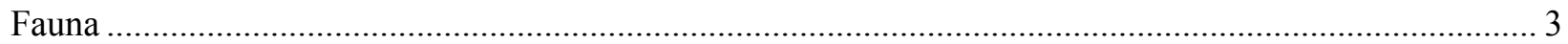

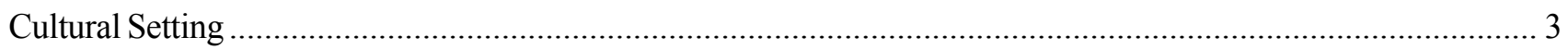

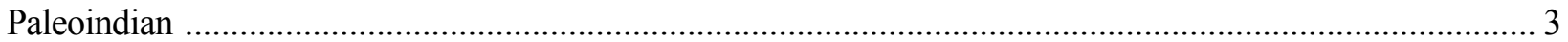

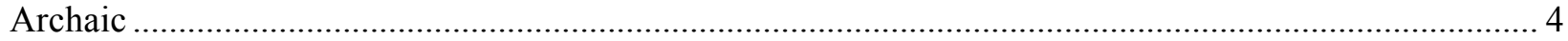

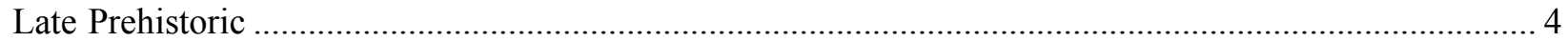

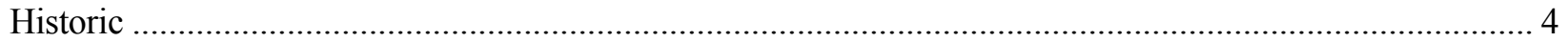

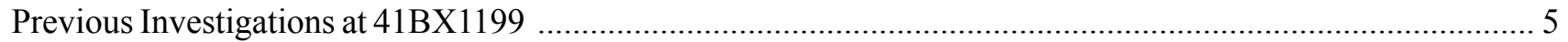

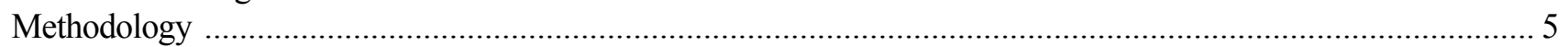

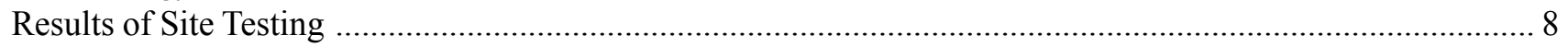

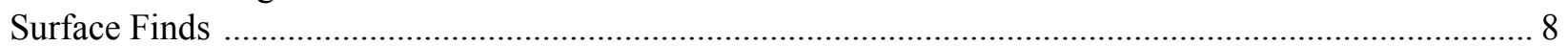

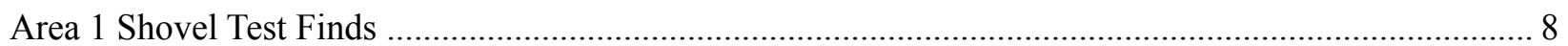

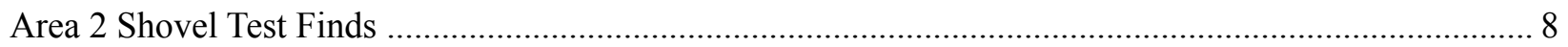

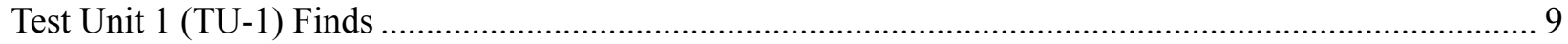

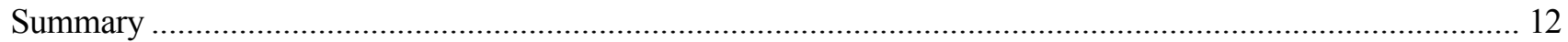

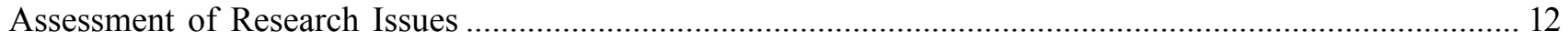

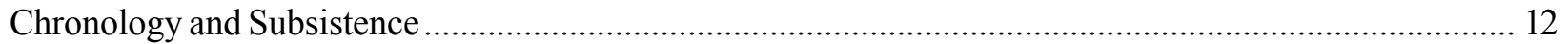

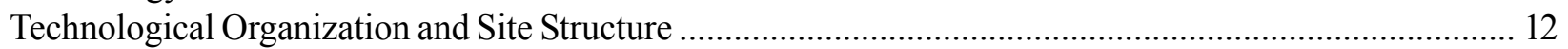

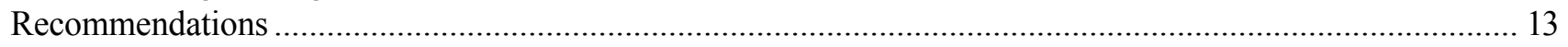

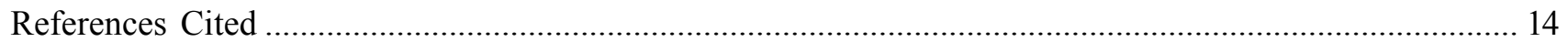




\section{Figures}

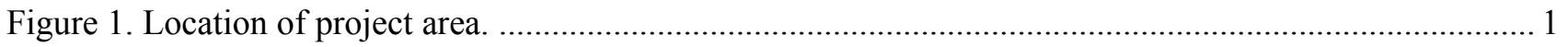

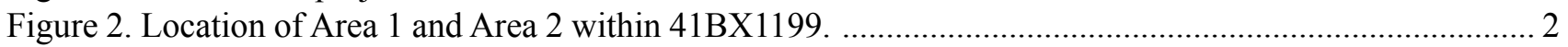

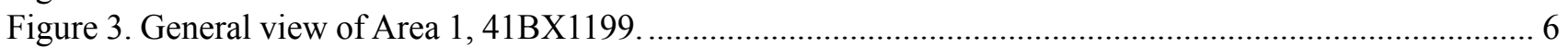

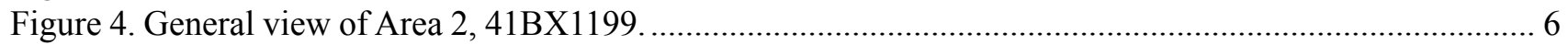

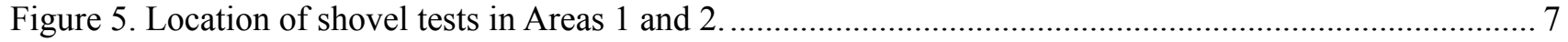

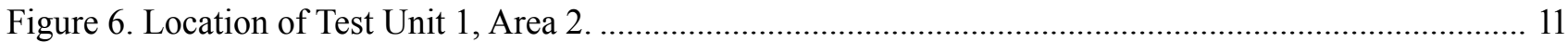

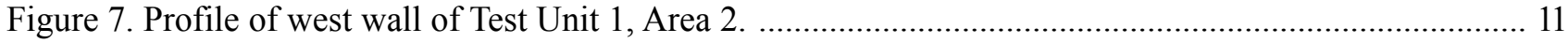

\section{Tables}

Table 1. Materials recovered from positive shovel tests excavated in Area 1 .............................................. 9

Table 2. Materials recovered by level from positive shovel tests excavated in Area 1 ................................. 9

Table 3. Materials recovered from positive shovel tests excavated in Area 2 ............................................. 10

Table 4. Materials recovered by level from positive shovel tests excavated in Area 2 .............................. 10

Table 5. Materials recovered by level from Test Unit 1, Area 2 ............................................................... 12 


\section{Acknowledgments}

The successful completion of this project is owed in a large part to the able and hard-working field crew and lab technicians that helped in the survey, testing, and laboratory processing of the recovered materials. They include the following individuals: Cory Broehm, Ruth Mathews, and Carol Villalobos. Bruce Moses and Dr. Raymond P. Mauldin collaborated on creating the GIS-based project and site maps. Maryanne King, Johanna Hunziker, and Jennifer Logan edited the text and worked on layout. Dr. Russell Greaves served as Principal Investigator on the project, while Dr. Steve A. Tomka served as co-Principal Investigator. The author would like to extend special thanks to Deirdre E. Hisler and all the Texas Parks and Wildlife Department staff at the Government Canyon State Natural Area for their hospitality and assistance. George Kegley, Cultural Resource Coordinator for Region 5, has been a pleasure to work with and has been instrumental in the rapid completion of this project. The help of one and all is greatly appreciated. 


\section{Introduction}

In May 2001, in advance of opening the Government Canyon State Natural Area for public use, the Texas Parks and Wildlife Department (TPWD) contracted with the Center for Archaeological Research (CAR), The University of Texas at San Antonio, to conduct a 100 percent pedestrian survey of the proposed trail systems within the property and to carry out National Register eligibility testing of site 41BX1199. The project area is located in northwest Bexar County, in southcentral Texas, and is under the ownership and management of the TPWD (Figure 1). CAR personnel conducted the testing of 41BX1199 under Texas Antiquities Permit 2582.
Site 41BX1199, approximately 68 acres in size, was originally documented and shovel tested by TPWD archaeologists in 1996 (McNatt et al. 2000:86-87). Plans to open the Government Canyon State Natural Area to public access necessitated the improvement of existing trail systems and the construction of new support facilities. Two facilities were proposed for construction in the relatively flat southern portion of the Natural Area encompassing site 41BX1199. Camping facilities, covering 11.6 acres ( 4.7 hectares), were to be constructed in the northeastern portion of the site, while picnic facilities, covering seven acres ( 2.8 hectares), were to be built in the west-central portion of 41BX1199 (Figure 2). The testing efforts carried out by CAR focused on these two areas.

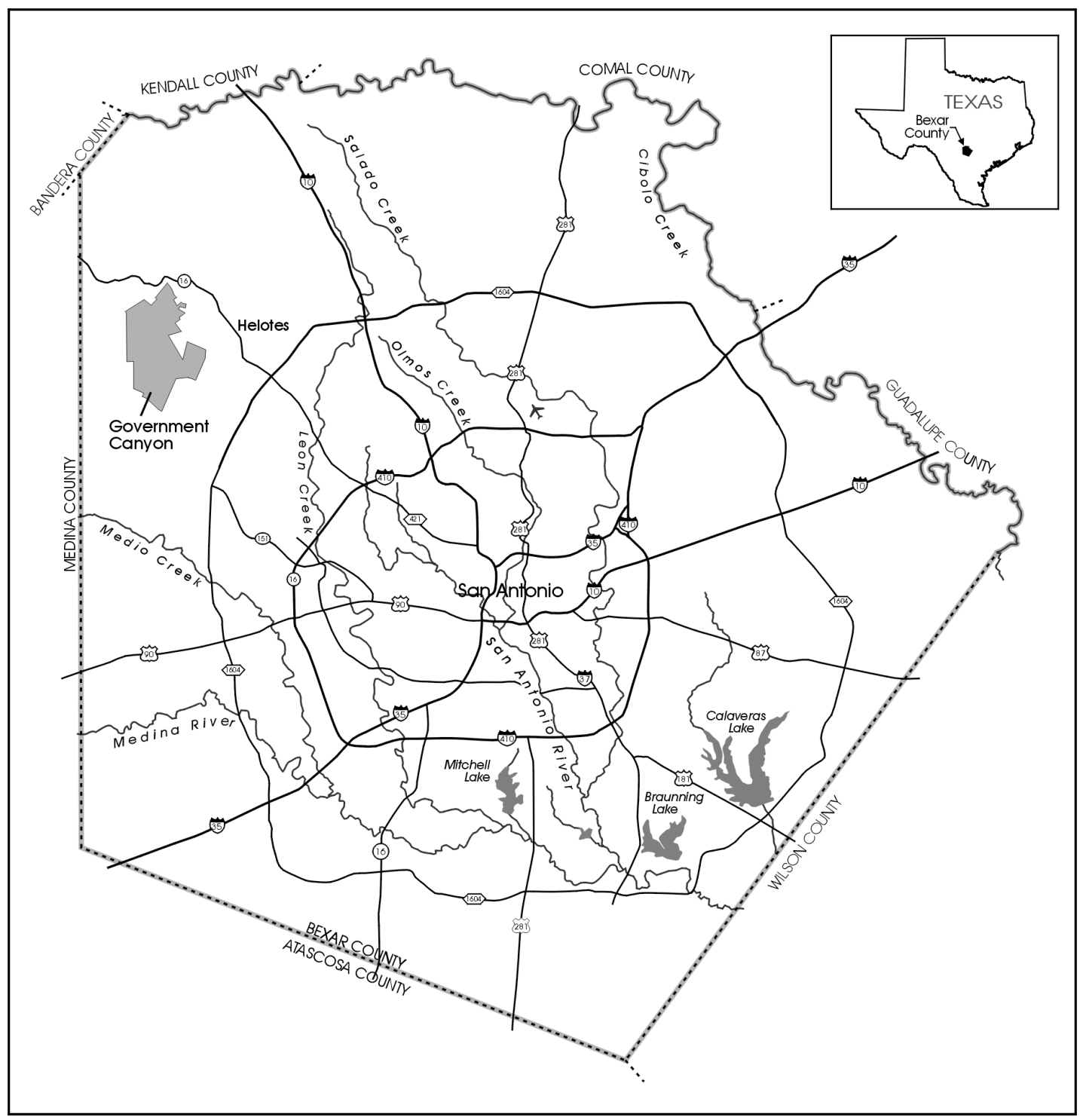

Figure 1. Location of project area. 
This report discusses the results of the test excavations performed at 41BX1199. Following this section, the report contains a brief description of the environmental and cultural setting, a review of previous investigations, and field methods employed during these investigations. Sections discussing the results of the test excavations, the assessment of the research issues, and recommendations regarding National Register of Historic Places (NRHP) and State Archeological Landmark (SAL) eligibility, complete the report.

\section{Environmental Setting}

\section{Geology}

Site 41BX1199, in the southern portion of the Government Canyon State Natural Area (SNA), is on a relatively flat landform that slopes gently to the south/ southwest. The site is at the base of limestone hills that are part of the Balcones Escarpment (Abbott and Woodruff 1986:2, 22). The escarpment separates the

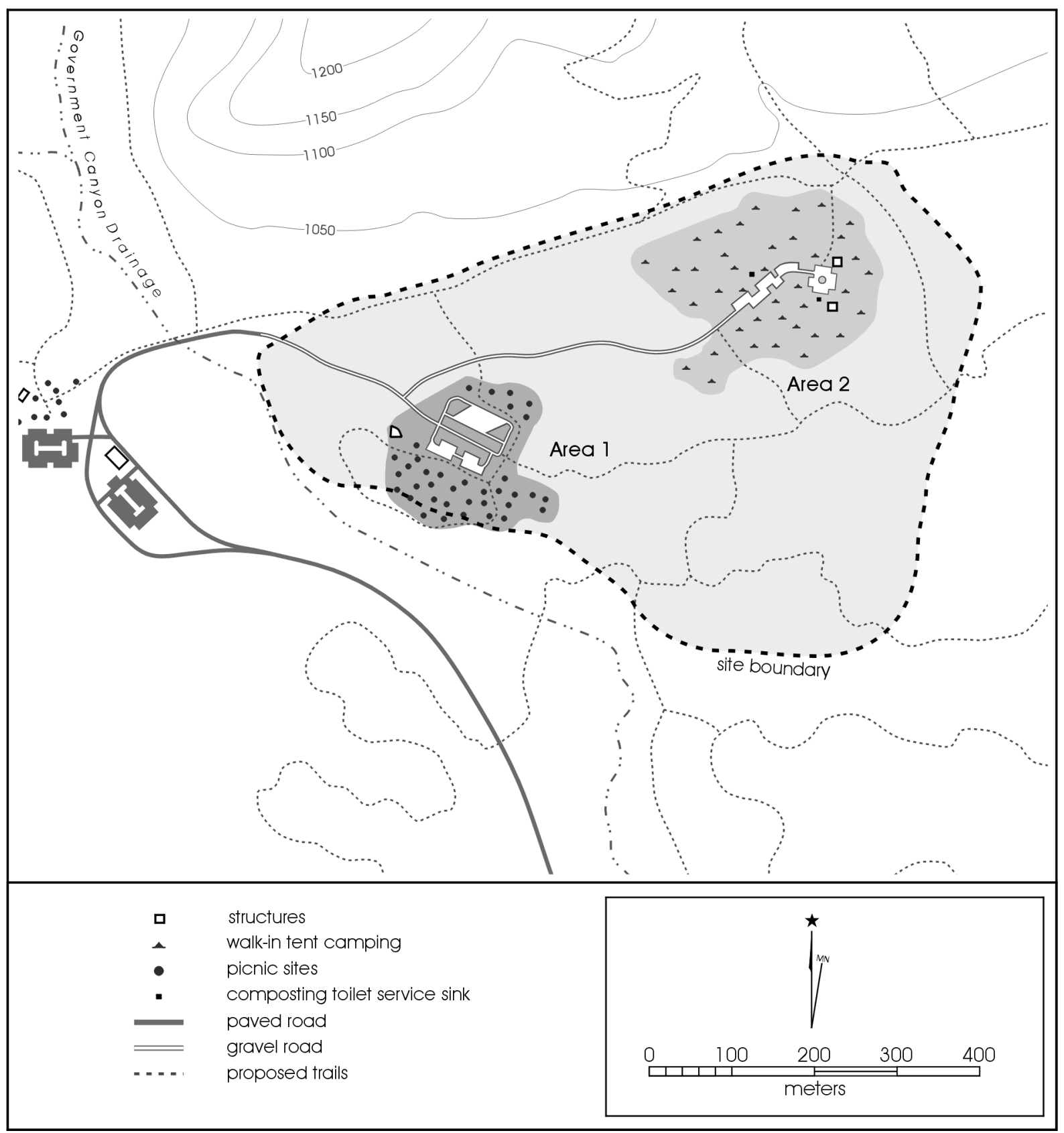

Figure 2. Location of Area 1 and Area 2 within 41BX1199. Adapted from TPWD 1998. 
Edwards Plateau from the West Gulf Coastal Plain via the Balcones Fault Zone (Abbott and Woodruff 1986:21). Undeveloped roads bound the site to the north and west. Part of the fault zone, the Haby Crossing Fault (McNatt et al. 2000:5), is the path taken by the north road. The Government Canyon Drainage lies to the west and a lesser drainage to the east (McNatt et al. 2000:89).

\section{Soil}

Terrant Association soils are gently undulating across the northern half of the site and Patrick soils occur on one to three percent slopes across the southern half (Taylor et al. 1966:27, 30, Sheet 25). Terrant Association soils are dark colored (black to very dark grayishbrown), calcareous, and clayey. The surface layer is approximately 10 inches $(25 \mathrm{~cm})$ thick and contains limestone fragments, cobblestones, and gravels. These are shallow soils overlaying limestone bedrock (Taylor et al. 1966:30). Patrick soils are dark colored (very dark grayish-brown to dark brown) and occur on level to gently sloped terrain. The surface layer is approximately 12 inches $(30 \mathrm{~cm})$ thick and is a silty clay, clay loam, or light clay. Buried Patrick soils are usually brown clay loam to light gray clay (Taylor et al. 1966:26, 27).

\section{Climate}

The climate of the area is modified subtropical. Winters are mild with the coldest monthly temperature in January and the hottest monthly temperature in August (Taylor et al. 1966:118, 120). The average low for January is $37.9^{\circ} \mathrm{F}$ and the average high for August is $95.3^{\circ} \mathrm{F}$ (Bomar 1995:219, 223). Rainfall is bimodal, peaking in May/June and September (Taylor et al. 1966:118, 120). May averages 4.22 inches, June 3.81 inches, and September 3.41 inches (Bomar 1995:230).

\section{Flora}

Government Canyon SNA is located in a transitional zone between South Texas Brush Country, the Blackland Prairies, and the Balcones Canyonlands (McNatt et al. 2000:8). Oak trees, genus Quercus (Kavanagh 2000), are scattered throughout 41BX1199, with concentrations along the southwest margin of the site where it borders Government Canyon Drainage and in the north/northeast as it nears the base of the escarpment. More widespread are junipers (Juniperus ashei), which cover much of the southern and western portion of the site (Gould 1975:17). In areas where the juniper have left room, a variety of smaller trees, bushes, shrubs, and prickly pear cactus (Opuntia phaeacantha) have invaded, creating a dense cover of vegetation (Elias and Dykeman 1990:140). In the central part of the site, grass cover is present over 60 percent of the area. To the north and east, where oaks outnumber juniper and brush, the grasses occur over less than 50 percent of the area.

\section{Fauna}

A variety of animal species were noted in the Government Canyon SNA. They include species of reptiles such as rattlesnakes, like the western diamondback (Crotalus atrox), the Texas horned lizard (Phynosoma douglassi brevirostre), and the Texas spiny lizard (Sceloporus olviaceus) (Conant 1975:102, 110, 236). Numerous birdcalls attested to the presence of diverse avian species, but only the roadrunner (Geococcyx californianus) (Robbins et al. 1983:172) was visually identified. Mammals noted were white-tailed deer (Odocoileus virginianus) (Davis 1974) and wild boar (Sus scrofa) (Ransom 1981:382).

\section{Cultural Setting}

Site 41BX1199 falls within the Central Texas Archaeological Region (Prewitt 1981:71). The Paleoindian period, from 11,500 Ве to 8800 вр (Collins 1995:380, 381), represents the earliest human habitation in Central Texas. It is followed by the Archaic period, extending from 8800 BP to 1200 вР (Collins 1995:383385). The Late Prehistoric period extends from 1200 BP to the late seventeenth century (European contact), with the Historic period lasting from the late seventeenth century to the present (Collins 1995:386).

\section{Paleoindian}

Clovis points and associated artifacts represent the earliest cultural manifestations of the Paleoindian period (11,500-8800 BP). The Clovis "lifeway" is one of hunting and gathering in territories, or rounds, that brought 
people to the same set of places time and again (Collins 1995:381, 382). Folsom points, spurred end scrapers, and ultra-thin bifaces represent the next Paleoindian cultural manifestation. The livelihood of people during the Folsom period seems to have been more nomadic and increasingly reliant on specialized hunting, rather than the generalized hunting-gathering adaptations practiced during Clovis times (Collins 1995:382). After Folsom, dart points began to change and diversify, as did other tools, indicating an increased variation in the lifestyles of the inhabitants of all of North America as well as Central Texas (Collins 1995:382).

\section{Archaic}

The Archaic period (8800-1200 вр) is commonly divided into three subperiods, Early Archaic (8800-6000 BP), Middle Archaic (6000-4000 BP), and Late Archaic (4000-1200 вР) (Collins 1995:383-385). In Central Texas, tools continue to reflect the diversification begun in the later part of the Paleoindian period. Shifting away from the specialized Folsom trend, food resources began to widen and reincorporate plant gathering (Collins 1995:383, 384). During the Early Archaic, heated rock began to be used as cooking elements in burned rock middens (Collins 1995:383), such as the one found in the northern end of the Government Canyon SNA (Dillehay 1972:13). These features are likely the result of food processing activities (Creel 1986:6570). The Archaic period cultures were affected by climatic fluctuations from mesic to extremely xeric conditions in the Middle Archaic and back to more mesic conditions in the Late Archaic (Collins 1995:384, 385). During wetter times people relied more on mesic plants like nuts, berries, and geophytes, and animals such as bison, deer, turkey, and aquatic species. In drier times they relied more on more xeric plants such as sotol (Collins 1995:383, 384).

\section{Late Prehistoric}

The Late Prehistoric (1200 BP-European contact), also termed Neoarchaic (Prewitt 1981:74), and the PostArchaic (Johnson and Goode 1994:5), saw the advent of the bow and arrow, followed by pottery (Collins 1995:385). European accounts of Central Texas in the time of contact seem to indicate the presence of large encampments, more populous than in earlier times.
These population and encampment patterns may have developed during the Late Prehistoric (Collins 1995:386).

\section{Historic}

European settlement began affecting Central Texas before direct contact in the late seventeenth century. The Spanish displaced southern groups, pushing them north into Central Texas, and European diseases began to reduce populations. Horses, introduced by the Spanish, facilitated the Apache advance southeast towards Central Texas (Collins 1995:386).

Southeast of the area around 41BX1199, the Spanish had established five missions in San Antonio de Bexar by 1731 . Comanche and Apache raids and political problems strangled European colonization efforts until the mid-1830s, when Mexican independence and an influx of Anglo-Americans provided the political impetus and population to fuel colonization and force out native inhabitants (McNatt et al. 2000:28, 29). By 1854, when Texas had been part of the United States for some years, supplying military forts had become a profitable business. To supply Camp Verde, Fort Terrett, and Fort McKavett, a trail ran up Government Canyon Drainage, perhaps passing near the site $(\mathrm{McNatt}$ et al. 2000:32-37).

Site 41BX1199 became part of a ranch when the tract on which it was located was surveyed in 1858. It was named the A. Jester Grant and signed to Hiram Keach (McNatt et al. 2000:40, 41). Between 1858 and 1880, several other tracts in the Government Canyon area were surveyed and purchased, but few were occupied. Exceptions were tracts owned by the Hoffmann family beginning in 1863. Around 1875, it was Jacob Hoffmann who purchased the land containing 41BX1199 (McNatt et al. 2000:42-46). In 1908, the Hoffmann Ranch was broken up in a family dispute. In 1928 a San Antonio businessman, William Lytle, purchased the largest portion of the Hoffmann Ranch. From the very beginning, the Hoffmann/Lytle Ranch was used to run cattle in the hills and grow feed crops in the flats (McNatt et al. 2000:53, 55). In 1966, the site was being utilized as pastureland (Taylor et al. 1966:Sheet No. 25) owned by William Lytle, Jr., until he sold the entire ranch to investors in 1967. A residential development was planned in 
the area until economic and environmental conflicts canceled the plan. In 1993, the Trust for Public Land purchased the ranch, and in 1994 the Texas Parks and Wildlife Department (TPWD) acquired the land (McNatt et al. 2000:55, 56).

\section{Previous Investigations at 41BX1199}

Between 1972 and 1996, 68 sites were recorded in the Government Canyon SNA. It was during this period that site 41BX1199 was recorded as part of the larger range of archaeological work done in the Government Canyon SNA (McNatt et al. 2000).

In 1996, the TPWD Archeology Survey Team surveyed 41BX1199 and dug five shovel tests in the site. Three had no artifact recovery, and after going through $67 \mathrm{~cm}, 34 \mathrm{~cm}$, and $19 \mathrm{~cm}$ of clay, each hit limestone bedrock (McNatt et al. 2000:86, 87). One of the two positive shovel tests yielded a burned rock from 0-10 $\mathrm{cm}$ below the surface (bs) and two pieces of debitage from $40-50 \mathrm{~cm}$ bs. This shovel test was ended at 58 $\mathrm{cm}$ bs after the sparse natural rock increased to dense gravels (McNatt et al. 2000:86-87). The second positive shovel test produced three chert heat spalls and two pieces of debitage. This shovel test was terminated at $77 \mathrm{~cm}$ bs, after encountering increased density of limestone fragments (McNatt et al. 2000:87).

The conclusion of this initial examination was that 41BX1199 had a low artifact density, appeared to be about 40 percent intact, and had a moderately high research potential. Further testing was recommended to determine the site's eligibility for SAL or NRHP nomination. It was also noted that the site might be at risk from erosion (McNatt et al. 2000:87).

\section{Methodology}

Research potential determines the site's eligibility for NRHP and SAL designation. In line with the Government Canyon project's research design, the main factors in determining the research potential are the site's temporal affiliation (i.e., identifying datable and diagnostic materials), subsistence evidence (i.e., microbotanical remains, well-preserved hearths), information relevant to technological organization (i.e., definable artifact assemblages), and data relevant to the reconstruction of the site's structure (i.e., location and nature of activity areas). Critical to all of these research issues is the integrity of archaeological deposits. The high risk of relic collecting from the site impacts research potential and may also influence NRHP and SAL eligibility. In light of these considerations, the testing efforts were designed to focus on determining the type and integrity of archaeological deposits present in the two areas subject to impact from construction.

Proposed development on 41BX1199 will impact two main areas of the site: Area 1, the picnic locations, and Area 2, the camping locations (Figures 2-4). To evaluate the site's research potential, CAR excavated 14 shovel tests (STs) in Area 1 and 35 in Area 2 (Figure 5).

In Area 1 the density of the vegetation made it difficult to layout a typical grid system of shovel tests. Fourteen shovel tests were laid out using a combination of pacing distances, a Brunton Pocket Transit for orientation along magnetic north, and machetes to cut through the brush. In Area 2, where grasses were more common and the ground more open, shovel tests were laid out using a Brunton Pocket Transit for orientation along magnetic north and a tape measure for more accurate spacing. A total of 23 shovel tests were laid out in this manner. Twelve additional shovel tests were excavated adjacent to positive shovel test units five meters to the north, south, east, and west of the original positive unit. Even in this open area, the density of juniper in a few places forced some variation in the grid.

Each shovel test was $30 \mathrm{~cm}$ in diameter and dug in 10 $\mathrm{cm}$ levels. The shovel tests were laid out to provide an even stratigraphic sampling of each area, which allowed a good assessment of the cultural deposits and increased the chances of finding features and artifact clusters. The location of each shovel test was recorded using a Trimble GPS unit. In both Areas 1 and 2, convenient clearings one to two meters off the grid were taken advantage of for clear readings with the GPS unit. Soil samples were taken from every level in the shovel tests for magnetic susceptibility testing conducted in the lab. The magnetic susceptibility test is useful in revealing soil layers impacted by cultural activities. The results of this analysis are not yet complete and are not included in this report. 


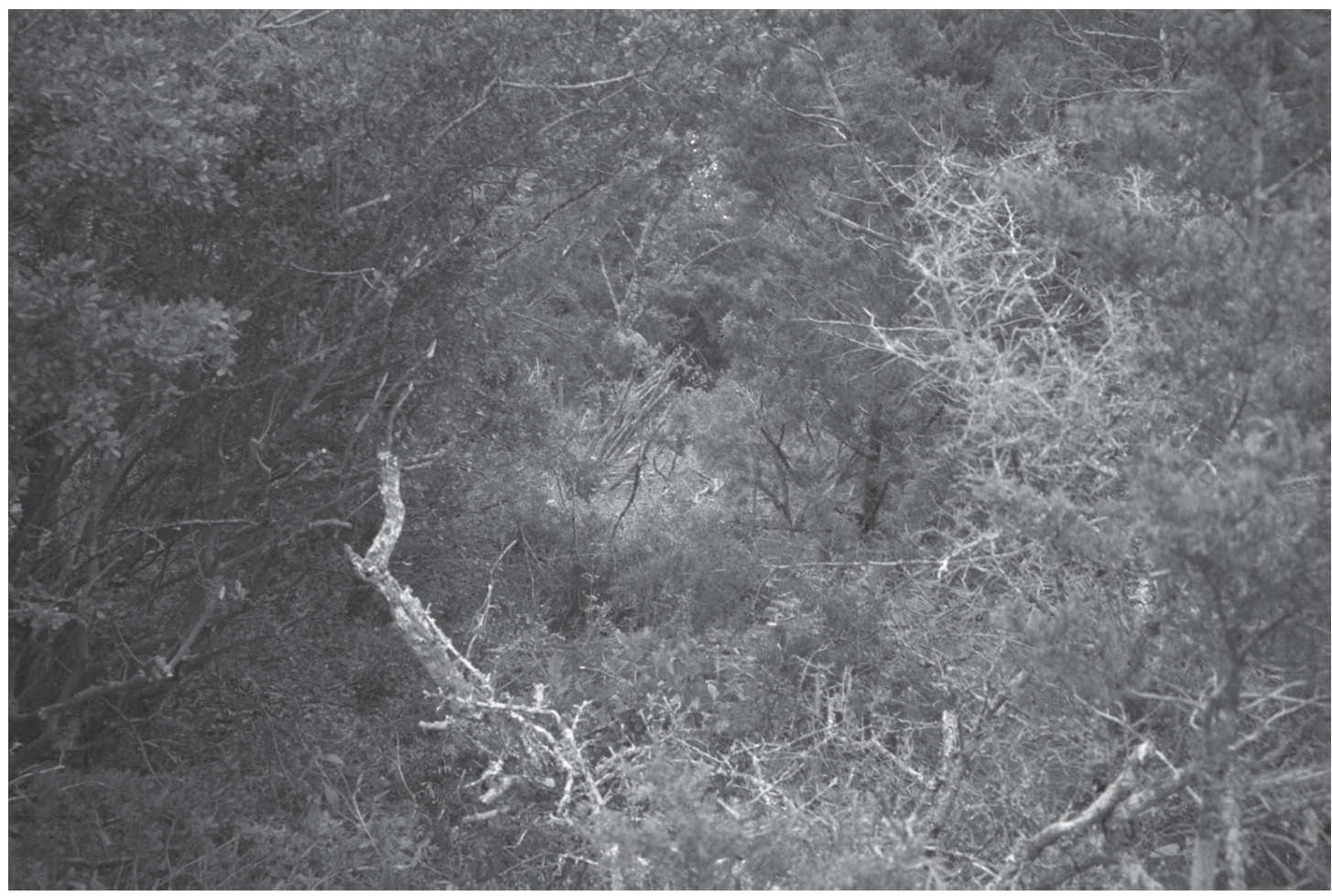

Figure 3. General view of Area 1, 41BX1199.

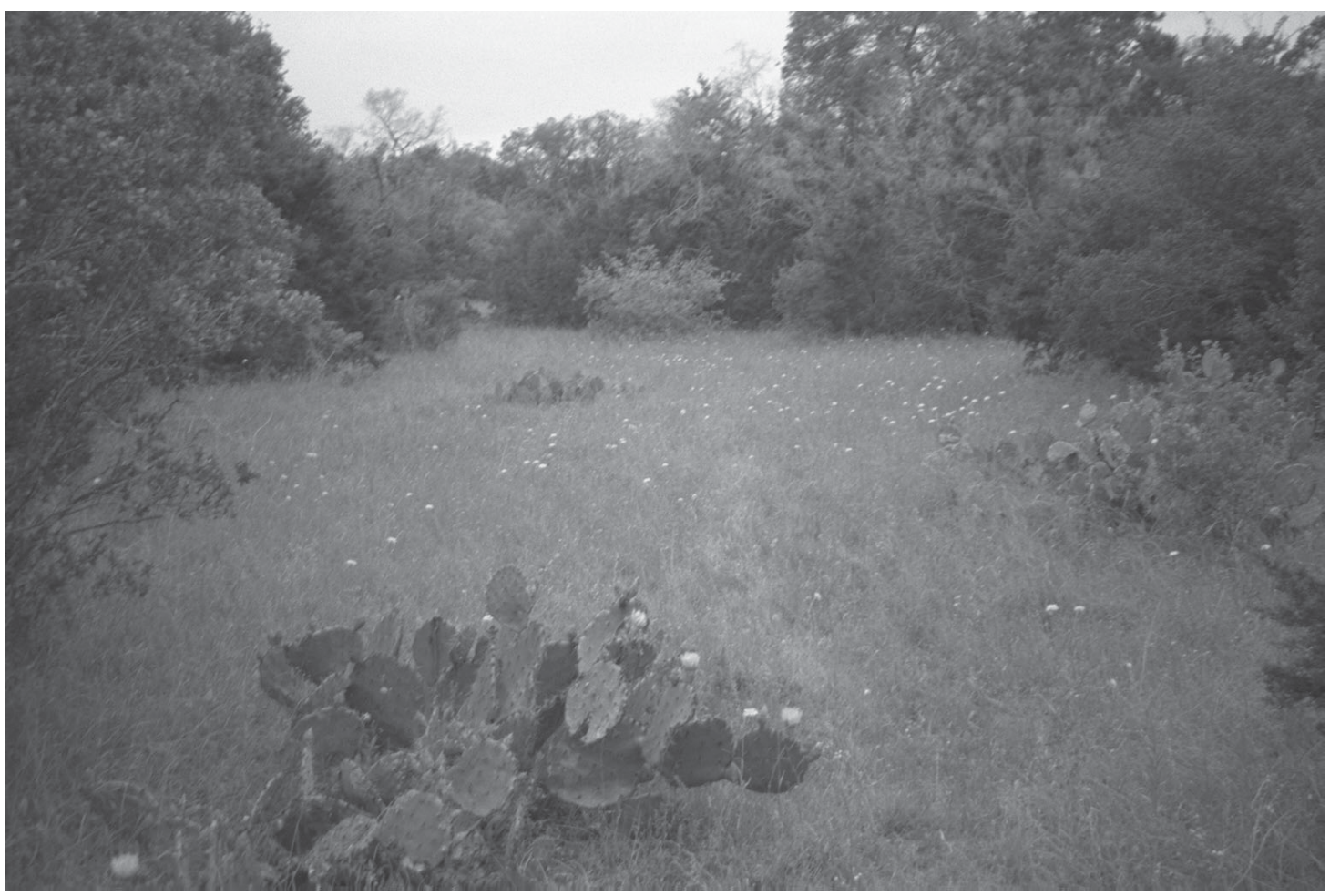

Figure 4. General view of Area 2, $41 B X 1199$. 


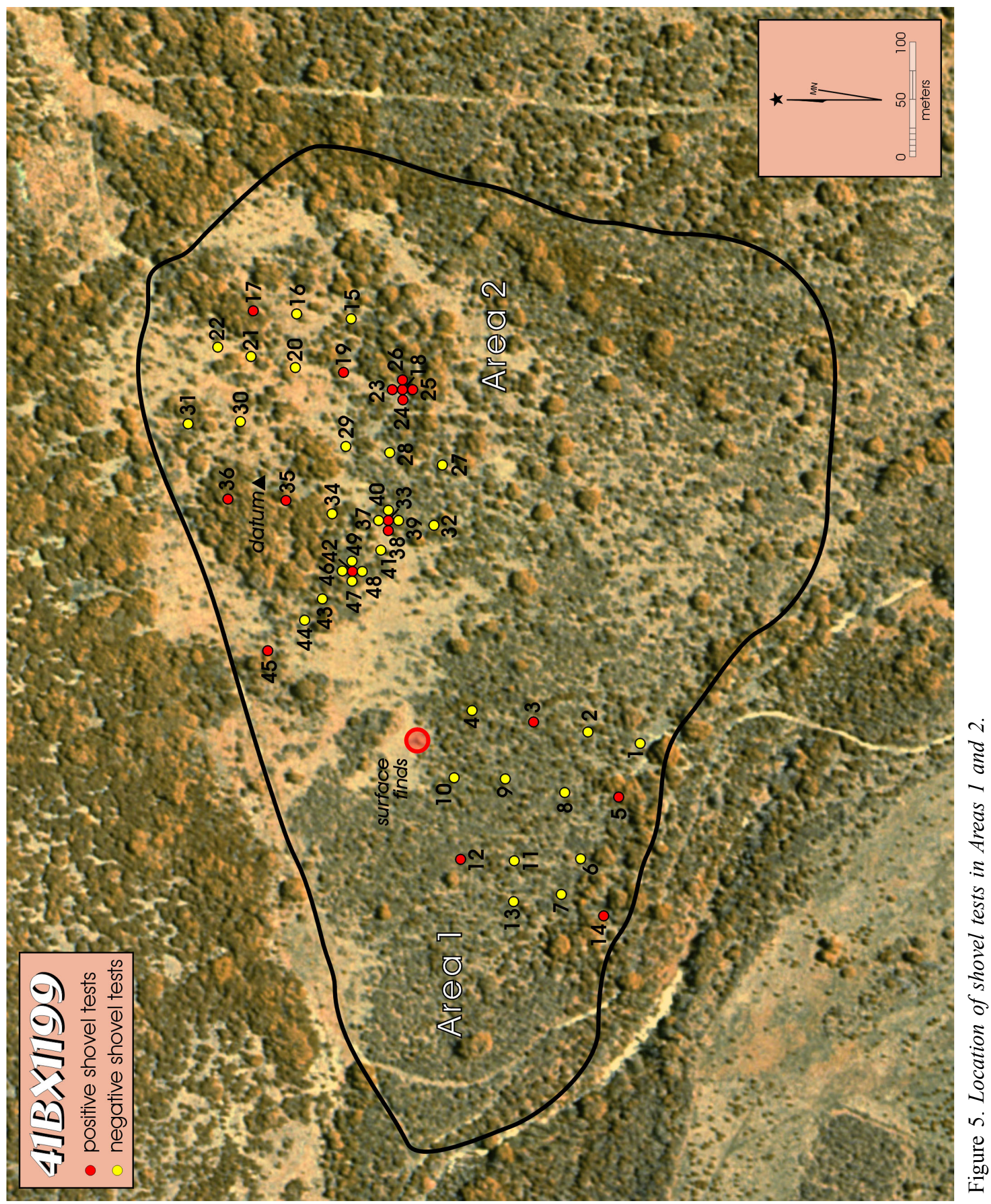


CAR archaeologists proposed the excavation of two 1-x-1-meter test units in each area to investigate any subsurface concentrations of artifacts and features discovered during shovel testing. One such feature was noted in Area 2 and explored with a 1-x-1-meter test unit. Soil samples were taken from each $10 \mathrm{~cm}$ level and magnetic susceptibility samples were extracted from each $5 \mathrm{~cm}$ level in the test unit.

All information related to shovel testing and excavation units was recorded on standardized forms. Photographs were taken on archival quality black and white $35 \mathrm{~mm}$ film and color slide film. All artifacts recovered were returned to the laboratory at CAR for processing and analysis.

\section{Results of Site Testing}

\section{Surface Finds}

Surface artifacts in Area 1 were sparse, but one scatter of debitage was noted outside the area while traversing between Areas 1 and 2 (Figure 5). The lithic scatter is estimated to be about two meters in diameter. There was a total of 19 flakes and an early-reduction stage biface in this circular scatter. As the scatter was outside Area 1, and none of the artifacts were temporally or functionally diagnostic, no specimens were collected. An additional artifact, a multidirectional core, was on the surface about five meters to the southwest of the concentration and just on the edge of the grassy clearing. Despite the unremarkable nature of the artifacts, the scatter is vulnerable to collecting and is near the road between the picnic (Area 1) and the camping locations (Area 2).

\section{Area 1 Shovel Test Finds}

The 14 shovel tests excavated in this area revealed a fairly consistent silty clay layer from the surface to between $5-10 \mathrm{~cm}$ bs. The silty clay layer extends to almost $30 \mathrm{~cm}$ bs in ST 3 . This silty clay layer is of a slightly lighter color than the soil below it. Natural limestone and chert fragments were present in nearly every level with large rocks occurring between 10-20 $\mathrm{cm}$ bs and decreasing in size with increasing depth. In the two shovel tests (STs 1 and 14) where bedrock was encountered (57 and $45 \mathrm{~cm}$ bs, respectively), the soil lightened noticeably just before contact.

Only four of 14 shovel tests (29 percent) dug in the area were positive (STs 3, 5, 12, and 14; Figure 5). None of the STs revealed artifact concentrations or other features, and no tools or diagnostic artifacts were encountered.

A total of four artifacts and a charcoal sample were recovered from the shovel tests (Table 1). No STs contained more than a single artifact, and three of the four artifacts are unmodified lithic debitage, while the fourth is a piece of fire-cracked rock (FCR).

Two of the unmodified debitage specimens came from Level 1 (STs 5 and 14), while the third is from Level 6 (ST 12; Table 2). It is likely that this artifact worked its way down through the profile in the numerous drying cracks present in the heavy clay soil. Two of the three pieces of debitage are secondary flakes and are the products of core and/or platform preparation. The third flake is a small tertiary flake. The lone piece of FCR comes from Level 2 (ST 3), while the charcoal sample was recovered from Level 1 (ST 5). Given the likelihood of recent brush fires and modern land clearing activities in the area, it is probable that the sample is of modern age and should not be retained for curation.

\section{Area 2 Shovel Test Finds}

The 35 shovel tests excavated in Area 2 revealed silty clay from the surface to around $10 \mathrm{~cm}$ bs. The deposits turned to clay below this depth. Soils are generally very dark gray to black and very shallow. Bedrock was reached in 24 ( 68.5 percent) of the 35 shovel tests. The depth of the bedrock ranged from $12-65 \mathrm{~cm} \mathrm{bs}$, with an average of $39 \mathrm{~cm}$ bs. Just before contact with bedrock, the soil lightens to a dark brown color and is sometimes accompanied by a layer of limestone fragments that increase in density with decreasing distance to bedrock. Excavation was terminated in two shovel tests after reaching the loose limestone layer at 40 and $50 \mathrm{~cm}$ bs, respectively.

Thirteen ( 37 percent) of the 35 shovel tests excavated in Area 2 (Figure 5) were positive, containing either unmodified debitage and/or FCR. In addition, charcoal 
Table 1. Materials recovered from positive shovel tests excavated in Area 1

\begin{tabular}{|c|c|c|c|c|}
\hline ST\# & Debitage & FCR & $\begin{array}{c}\text { Charcoal } \\
\text { Sample }\end{array}$ & Total \\
\hline \hline 3 & 0 & 1 & 0 & 1 \\
\hline 5 & 1 & 0 & 1 & 2 \\
\hline 12 & 1 & 0 & 0 & 1 \\
\hline 14 & 1 & 0 & 0 & 1 \\
\hline Total & 3 & 1 & 1 & 5 \\
\hline
\end{tabular}

Table 2. Materials recovered by level from positive shovel tests excavated in Area 1

\begin{tabular}{|c|c|c|c|c|}
\hline Level & Debitage & FCR & $\begin{array}{c}\text { Charcoal } \\
\text { Sample }\end{array}$ & Total \\
\hline \hline 1 & 2 & 0 & 1 & 3 \\
\hline 2 & 0 & 1 & 0 & 1 \\
\hline 6 & 1 & 0 & 0 & 1 \\
\hline Total & 3 & 1 & 1 & 5 \\
\hline
\end{tabular}

was noted in Level $1(0-10 \mathrm{~cm}$ bs $)$ of ST 49 . Given its shallow context, it was assumed to be modern and was not collected.

Nine (69 percent) of the 13 positive shovel tests yielded a total of 15 pieces of debitage (Table 3 ). The debitage is dominated by corticate specimens $(\mathrm{n}=12,80$ percent) that appear to be the products of core and/or platform preparation and early stage reduction. A total of 36 pieces of FCR was recovered from eleven shovel tests.

Both the debitage and the FCR tend to concentrate in Level 1 (63 percent; Table 4). Artifact densities tend to drop with increasing depth, with the exception of a small increase in FCR in Level 3 (STs 24 and 33 have three and four small pieces, respectively). Only two pieces of lithic debitage were recovered in Level 4 (STs 18 and 23), the deepest of the positive levels.

\section{Test Unit 1 (TU-1) Finds}

To test whether the charcoal from the uppermost level of ST 49 represented a modern burning episode rather than a possible prehistoric thermal feature, a 1-x-1meter test unit (TU-1) was hand-excavated, overlapping the north edge of ST 49 (Figure 6). ST 49 is located in the vicinity of STs 42 and 48 on the edge of a slight rise (Figure 6). The change in elevation from ST 48, which is below the rise, to ST 42 on the rise is only 34 $\mathrm{cm}$. Shovel tests $42,46,47,49$, and TU-1, located near the top of the rise, indicate that the bedrock is relatively shallow, averaging only $37 \mathrm{~cm}$ bs. On the other hand, ST 48, located below the edge of the rise, reached bedrock at a depth of $52 \mathrm{~cm} \mathrm{bs} \mathrm{(Figure} \mathrm{6).} \mathrm{This}$ difference in the thickness of the soils suggests that the uppermost portion of the site has been subject to relatively severe sheet wash and erosion with a significant amount of soil being redeposited onto lower portions of the site (Figure 6).

The test unit excavation revealed that the upper three centimeters of Level $1(0-10 \mathrm{~cm} \mathrm{bs})$ is organic material from the surrounding trees and brush. The underlying $17 \mathrm{~cm}$ of matrix represents a transition zone from clay loam to clay. A few isolated natural limestone and chert nodules are present throughout the deposit. The organic layer is a dark brown color and all underlying soils are black (Figure 7). The bottom 5-10 cm of deposits contained large quantities of fragmented limestone nodules that represent eroding bedrock (Figure 7).

Three 10-cm levels were excavated in the relatively shallow matrix. The excavation was halted at 30 $\mathrm{cm}$ bs at a layer of limestone fragments commonly 
Table 3. Materials recovered from positive shovel tests excavated in Area 2

\begin{tabular}{|c|c|c|c|}
\hline ST\# & Debitage & FCR & Total \\
\hline \hline 17 & 1 & 6 & 7 \\
\hline 18 & 1 & 3 & 4 \\
\hline 19 & 2 & 1 & 3 \\
\hline 23 & 3 & 2 & 5 \\
\hline 24 & 1 & 3 & 4 \\
\hline 25 & 0 & 4 & 4 \\
\hline 26 & 1 & 0 & 1 \\
\hline 33 & 0 & 5 & 5 \\
\hline 35 & 0 & 3 & 3 \\
\hline 36 & 1 & 0 & 1 \\
\hline 38 & 1 & 6 & 7 \\
\hline 42 & 4 & 1 & 5 \\
\hline 45 & 0 & 2 & 2 \\
\hline Total & 15 & 36 & 51 \\
\hline
\end{tabular}

Table 4. Materials recovered by level from positive shovel tests excavated in Area 2

\begin{tabular}{|c|c|c|c|}
\hline Level & Debitage & FCR & Total \\
\hline \hline 1 & 10 & 22 & 32 \\
\hline 2 & 3 & 3 & 6 \\
\hline 3 & 0 & 7 & 7 \\
\hline 4 & 2 & 4 & 6 \\
\hline Total & 15 & 36 & 51 \\
\hline
\end{tabular}

indicative of the upper reaches of bedrock. A total of 103 artifacts were recovered, consisting of FCR $(n=100)$ and unmodified debitage $(n=3)$ (Table 5).

In addition, five charcoal samples were recovered, three from the uppermost level and two from Level 2 (10-20 $\mathrm{cm}$ bs). Two snails (Helicina sp.) were encountered in Level 1 (0-10 cm bs) and three (two Rabdotus sp., one Helicina sp.) in Level $2(10-20 \mathrm{~cm}$ bs). The snails occur in low frequencies and are not likely to be the discarded remains of food consumption.

Two of the three flakes are small tertiary platformpreparation removals, while the third is a corticated specimen. They were evenly distributed between the levels. The majority (79 percent) of the FCR were found in Level 2 (10-20 cm bs). Level 1 contained smaller quantities, and only three pieces ( 3 percent) were found in Level 3.
A small hearth feature, Feature 1, was identified in Level 1 and continued into Level 2. The feature consisted of a small oval $(25 \times 18 \mathrm{~cm})$ unlined hearth with a large quantity of partially burned, well-preserved wood charcoal and large numbers of FCR. The upper lip of the hearth was detected at $5 \mathrm{~cm}$ bs in Level 1. The base of the pit was at $14 \mathrm{~cm}$ bs in Level 2. The large quantity of FCR noted in Level 2 does not represent the lining of the hearth. Rather, it is the product of the heating of the limestone and chert pebble substrate that caps the bedrock. Given that Feature 1 is only

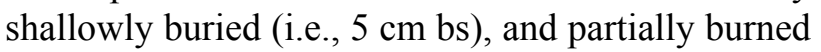
charcoal and wood fragments are common in the level, it is likely that the feature is of historic or modern origin. Nonetheless, five charcoal samples were collected from the feature (three from the upper part and two from its base) in case the need arises for a radiocarbon date. These samples have not been submitted for radiocarbon age determination given the feature's suspected modern origin. 


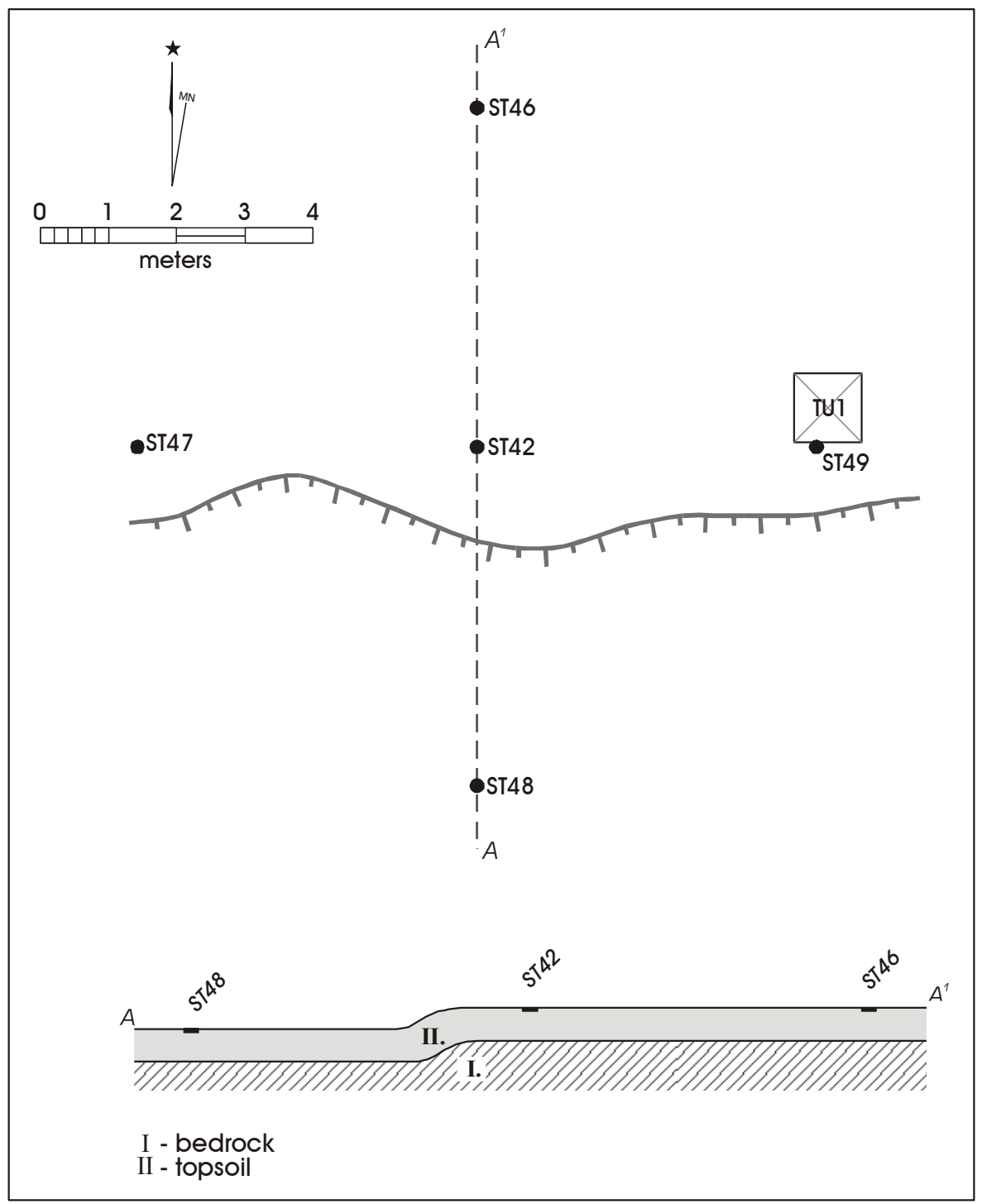

Figure 6. Location of Test Unit 1, Area 2.

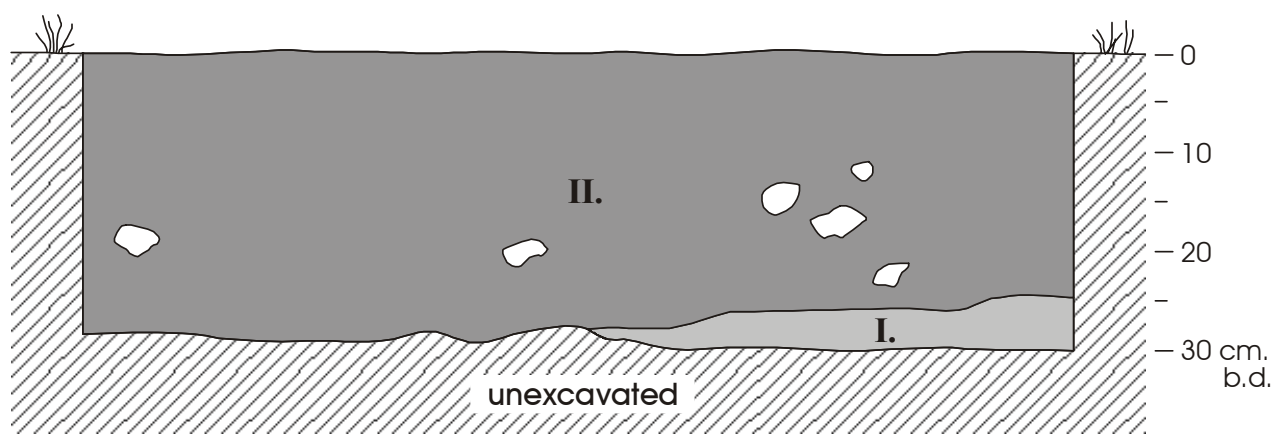

\section{I - bedrock \\ II - topsoil}

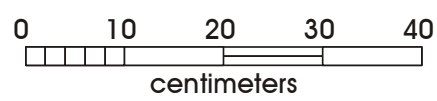

Figure 7. Profile of west wall of Test Unit 1, Area 2. 
Table 5. Materials recovered by level from Test Unit 1, Area 2

\begin{tabular}{|c|c|c|c|c|c|}
\hline Level & Debitage & FCR & $\begin{array}{c}\text { Charcoal } \\
\text { Sample }\end{array}$ & Snail & Total \\
\hline \hline 1 & 1 & 18 & 3 & 2 & 24 \\
\hline 2 & 1 & 79 & 2 & 3 & 85 \\
\hline 3 & 1 & 3 & 0 & 0 & 4 \\
\hline Total & 3 & 100 & 5 & 5 & 113 \\
\hline
\end{tabular}

\section{Summary}

Archaeological testing of the two main areas to be impacted by the construction of a camping facility at site 41BX1199 resulted in the excavation of 14 shovel tests in Area 1 and 35 shovel tests and one 1-x-1meter unit in Area 2. A single feature was identified in Area 2; it is a small, shallow, pit with unlined, burned walls and abundant charcoal. Given that the feature is shallowly buried, and abundant well-preserved, partially burned wood fragments are associated with it, a modern or historic origin is likely.

A total of 158 artifacts consisting of FCR $(n=137)$ and unmodified debitage $(n=21)$ were recovered from the two areas. Area 2 yielded the majority of artifacts $(n=51)$, while about one-third came from Area $1(n=4)$. In addition, six charcoal samples, five from TU-1 (Levels 1 and 2) in Area 2 and one from ST 5 (Level 1) and five snails were recovered (TU-1, Levels 1 and 2).

Because of the high density of FCR at the base of Feature 1, Level 2 yielded about one-half of the total artifacts from the site ( $\mathrm{n}=87,55$ percent), while Level 1 produced about one-third of the materials $(n=53,33.5$ percent). In general, artifact densities decrease substantially below Level 2 . One artifact (1.3 percent) was recovered from Level 6 (ST 12), however, it may have been introduced there through the numerous cracks that are common in clay soils. Aside from this anomaly, no artifacts were found deeper than $40 \mathrm{~cm}$ bs.

\section{Assessment of Research Issues}

\section{Chronology and Subsistence}

No temporally diagnostic artifacts or formal and/or expedient tools were recovered during testing. It is likely that the six charcoal samples recovered from various proveniences at the site are of recent origin, as well as the single feature identified during excavation of TU1 in Area 2. Therefore, it is likely that these samples cannot help establish the age of the prehistoric remains uncovered at the site. Similarly, the sparse scattering of FCR across the site and in Level 1 suggest that modern or recent burning activities may account for its presence. The small number of Rabdotus and Helicina snails recovered are clearly intruders into the deposits and do not constitute subsistence indicators. In addition, no bone was recovered during excavations. Given the absence of temporal diagnostic artifacts, charcoal of questionable origin, and the likelihood that the single feature identified at the site is of modern origin, 41BX1199 has no potential to contribute chronological and/or subsistence-related data.

\section{Technological Organization and Site Structure}

Information on technology at the site is more readily available than information on chronology or subsistence. Debitage from Areas 1 and 2 consists mostly of secondary $(n=13)$ and tertiary flakes $(n=5)$. At least one concentration of debitage is present on the surface of 
the site near Area 1. The presence of a single earlyreduction stage biface in combination with the predominance of secondary debitage is indicative of lithic raw material procurement activities. The absence of formal and expedient tools may support this interpretation. Given that the majority of the debitage occurs on the surface and in Level 1, and portions of the site appear to be deflated through erosion, it is impossible to determine with certainty whether these artifacts form a behaviorally associated assemblage or just a group of artifacts brought together by post-depositional agents. Therefore, the collection of chipped lithic artifacts from 41BX1199 offers very little in the way of understanding the technological organization of groups utilizing the site, and given the disturbed nature of the upper deposits, additional work would add little information of interpretive value.

The deflated and locally eroded condition of 41BX1199 makes the definition of prehistoric activity areas unlikely. Two possible activity areas do exist. The first is Feature 1 and the second is the exposed lithic scatter noted near, but outside of, Area 1. Feature 1 appears to be of recent age, and animal burrowing heavily disturbs the surface lithic scatter. In light of these factors, the potential to reconstruct the structure of activities at the site is very low.

\section{Recommendations}

Proposed development on 41BX1199 will impact two main areas of the site: Area 1, the picnic locations, and Area 2, the camping locations. Based on the archaeological work conducted by CAR, it can be concluded that both areas have low research potential. These areas have been eroded and deflated, and have shallow soils with low densities of cultural materials, some of which may be of modern age.

The sparse buried deposits are safe from casual relic collecting, and the fact that surface deposits lack diagnostics suggests that few of these artifacts would be recognized as produced by humans, reducing the risk of their removal from the site. The surface and shallow archaeological deposits will be vulnerable to impact by construction of the roadway between the picnic and camping locations, however, their low research value does not warrant the mitigation of these impacts through further archaeological work.

The long-term equestrian trail traffic and pedestrian traffic on paths to the campsites will undoubtedly expose artifacts on occasion. It is recommended that these areas be periodically examined for exposed artifacts. The few formal artifacts that may come to light as a result of this impact may be collected, assigned to a general surface provenience on site, and used in park-related exhibits and public outreach presentations offered to park visitors. It is further recommended that an archaeologist monitor the work carried out in $\mathrm{Ar}$ eas 1 and 2 and document any intact cultural materials, if and when encountered. 


\section{References Cited}

Abbott, P. L., and C. M. Woodruff, Jr.

1986 The Balcones Escarpment, Geology, Hydrology, Ecology and Social Development in Central Texas. Prepared for the Annual Meeting of the Geological Society of America, San Antonio.

Bomar, G.

1995 Texas Weather. University of Texas Press, Austin.

Collins, M. B.

1995 Forty Years of Archeology in Central Texas. Bulletin of the Texas Archeological Society 66:380386.

Conant, R.

1975 A Field Guide to Reptiles and Amphibians of East and Central North America. Houghton Mifflin, Boston, Massachusetts.

Creel, D. G.

1986 A Study of Prehistoric Burned Rock Middens in West Central Texas. University Microfilms International, Ann Arbor, Michigan.

Davis, W. B.

1974 The Mammals of Texas. Bulletin No. 41. Texas Parks and Wildlife Department, Austin.

Dillehay, T. D.

1972 An Initial Archaeological Reconnaissance of Areas to be Affected by the San Antonio Ranch New Town, Bexar County, Texas. Research Report No. 13. Texas Archaeological Salvage Project, University of Texas, Austin.

Elias, T. S., and P. A. Dykeman

1990 Edible Wild Plants: A North American Field Guide. Sterling Publishing Company, New York.

Gould, F. W.

1975 Texas Plants: A Checklist and Ecological Summary. Texas Agricultural Experiment Station, Texas A\&M University, College Station.

Johnson, L., and G. T. Goode

1994 A New Try at Dating and Characterizing Holocene Climates, as well as Archaeological Periods, on the Eastern Edwards Plateau. Bulletin of the Texas Archeological Society 65:5-51.

Kavanagh, J.

2000 Texas Trees and Wildflowers: An Introduction to Familiar Species. Waterford Press, Blaine, Washington.

McNatt, L., C. Beceiro, M. D. Freeman, M. Howard, S. A. Tomka, P. Schuchert, and C. G. Ward

2000 Archeological Survey and History of Government Canyon State Natural Area, Bexar County, Texas. Texas Parks and Wildlife, Cultural Resources Program, Austin. 
Prewitt, E. R.

1981 Cultural Chronology in Central Texas. Bulletin of the Texas Archeological Society 52:71-89.

Ransom, J. E.

1981 Harper and Row's Complete Field Guide to North American Wildlife. Western edition. Harper and Row, New York.

Robbins, C. S., B. Bruun, and A. S. Zim

1983 A Guide to Field Identification: Birds of North America. Golden Books, New York.

Taylor, F. B., R. B. Hailey, and D. L. Richmond

1966 Soil Survey of Bexar County Texas. United States Department of Agriculture, Soil Conservation Service, Washington, D.C.

Texas Parks and Wildlife Department (TPWD)

1998 Government Canyon S.N.A. Master Plan Recreational Facilities Map. Government Canyon State Natural Area Master Plan, prepared by C. Beckcom. Texas Parks and Wildlife Department, Infrastructure Division, Austin. 